Proceedings

\title{
Maturity of a Condominium for Renovation: What Are the Influential Criteria? Analysis in the French Context ${ }^{+}$
}

\author{
Theo Henriel 1,2,* , Claire Oms ${ }^{1}$, Marc Mequignon ${ }^{2}$, Damien Arbault ${ }^{3}$ and Gilles Escadeillas ${ }^{1}$ \\ 1 Laboratory of Materials and Durability of Constructions (LMDC), 31400 Toulouse, France; oms@insa- \\ toulouse.fr (C.O.); escadeillas@insa-toulouse.fr (G.E.) \\ 2 Laboratory of Applied Studies and Research in Social Sciences (LERASS), 31400 Toulouse, France; \\ marc.mequignon@free.fr \\ 3 France; Damien@palanca.fr \\ * Correspondence: theohenriel@gmail.com; Tel.: +33-6-8239-1660 \\ † Presented at Sustainable Places 2018 (SP2018) Conference, Aix-les Bains, France, 27-29 June 2018. \\ Published: 19 December 2018
}

\begin{abstract}
In recent decades, much work has been done to facilitate the technical aspect of building renovation. However, the efforts made in housing renovation, especially in condominiums, are not sufficient to meet energy transition targets. In this specific type of building, the decision-making process is complex and is influenced by multiple factors. This study attempts to highlight the determining criteria that influence the renovation of a condominium. Obviously, technical and economic factors are important, but many sociological criteria also come into play. These criteria will be integrated into an analyzing tool which will be able to propose, in addition to the proper technical solution for renovation, the best accompaniment in the decision-making process.
\end{abstract}

Keywords: renovation; comfort; condominium; sociology; decision tool

\section{Introduction}

France is committed to dividing its GHG (greenhouse gas) emissions by 4 (so-called "factor 4" target) by 2050. This priority appears increasingly in political discourse. Whereas, in the recent past, controlling our energy consumption was strongly advocated by the ecology party only, today it is a common denominator among almost all political parties. As the construction industry accounts for more than $43 \%$ of final energy consumption in France, taking action to reduce consumption in new constructions (RT 2005 then RT 2012) is a priority policy of the government. However, the effort cannot be restricted to new constructions: it is of primary importance to intensify the industry of building renovation [1,2]. A report from project ATHEBA [3] shows the low energy quality of buildings built during the "Thirty Glorious Years" of the post-war boom of 1945-1975, in which there were no regulatory obligations concerning power quality.

The aim of this paper is to identify and classify the remaining barriers that hinder the renovation of buildings, and especially of condominium.

\section{Brakes and Levers Concerning Condominium Renovation}

In France, many programs have been set up to help the owners of individual houses to take the right decisions in thermal renovation. A lot of studies have been done in this field, and the number of efficient renovations is increasing. However, very few people work on condominiums, even though they represent a large proportion of housing in terms of surface area and their energy 
consumption is far from negligible. In order draw maximum advantage from our study, we choose to focus on the condominiums:

- A more complex and slower decision-making:

The condominium is undoubtedly the type of housing for which the decision-making process is the most complex and depends on so many different factors. This is due to the number of participants in the decision-making process: the agent managing the condominium, the numerous owners, either occupants and non-occupants, and eventually tenants. This specific structure has a much slower and more uncertain [4] decision-making process and requires appropriate human management to successfully achieve the project [5].

This complex organization does not facilitate the decision-making process. In most cases, important decisions are taken at a general assembly (GA), which is held once a year. In addition, the law also regulates decision-making at these General Assemblies.

Such cumbersome organization and decision-making complexities leave the co-owners with restricted initiative in the management of their own "property". In his PhD, G. Brisepierre [6] mentions North-American condominiums, where decision-making is simplified (thanks to broad delegation of authority to the Condominium Council through elections, on the basis of detailed programs, decisions taken by a majority of owners and not depending on the number of units owned).

- The complicated role of the management office:

A large majority of condominium maintenance missions are entrusted to a professional manager who assists the syndicate of co-owners. The service is paid for by the latter to ensure the proper functioning of the condominium. The manager acts not only on technical aspects (maintenance management, work interviews), economic aspects (collection of fees, service providers) but also on legal aspects and, more particularly, on the respect of condominium rules.

Because of the many roles that a professional management office should have, condominium managers are becoming less technical and more generalist, so as to handle legal and economic issues better. Therefore, they are not able to play the role of prescriptors for any thermal renovations.

- $\quad$ The complexity of financial aids:

If the financial aid system may seem complex for individuals, it is even more so for co-owners of condominiums. The occupants are involved in collective funding for the works regarding common areas, and individual funding for the works related to their own apartment (door and window replacements for example). Financial subsidies can be obtained from several organizations (ANAH, city, Eco PTZ, EEC, region, etc.) in different proportions for each occupant, with an individual part and a collective part [7]. Non-occupying owners present other specificities that trigger ever more particular situations.

All these specific brakes on renovation bring out a need for support in several areas: the decisionmaking process, the technical choices, and the financial aid, which are now identified by specialists but are still not subsidized enough. This duality between the time needed to finance and settle the projects and the difficulty in financing this long period itself makes the operations of restoration in a condominium very complex.

However, all around France, a certain number of rehabilitations take place on condominiums. It must be possible to carry out an analysis of these achievements, and to highlight certain criteria that influence the success of a restoration.

We also observed studies on condominiums that decided to pay for a renovation, and analyzed the determining factors. We correlated these studies with work by sociologists specializing in behavior and decision-making in terms of energy saving, and also with feedback from specialized research departments and renovation professionals. 
The purpose here is to identify any variable (technical, economic, architectural, urban, or social), that helps a renovation project to move forward, in order to extract the most significant ones and compile them in a tool dedicated to the evaluation of the potential for success in future projects of condominium renovation.

\section{List and Possible Grouping of Criteria}

In the literature, there are many qualitative, statistical, or simply descriptive studies that examine the influence of social, economic and technical parameters on a building's renovation. However, to our knowledge, none of them bring together all of these parameters, and none try to balance them by taking their relative importance into consideration.

To allow more efficient comparison among parameters, we chose to group them into 5 main categories:

- The functional quality and safety of the building

- The economic potential of the occupants (and of the building)

- The technical quality of the building

- The sociological profile of the occupant

- The urban and architectural potential of the building

\subsection{The Functional Quality and Safety of the Building}

For several years now, ADEME (the French Agency for the Environment and Energy Control) has been running the OPEN Program (Permanent Observatory of Energy improvement of housing), which evaluates the number and type of energy renovations in residential apartment buildings. This observatory also lists the motivations of the households to choose an energy renovation.

In its 2015 report, ADEME stated that nearly 300,000 renovations were carried out (including simple renovation, and complete renovation). In nearly $50 \%$ of the energy saving restorations, the reduction of consumption and the energy bill was not mentioned by the occupants. Other studies converge towards these observations [8] and propose several levers of motivation to undertake renovation works:

- Improvement of comfort (thermal-acoustic-humidity - comfort of use of the building)

- Global improvement of living environment

- Valorization of an estate's assets

- Replacement of decayed part of the building.

- Adaptation of living environment to the evolution of the occupants' needs (extensions, expansion).

Those studies, which can be combined with the work of C. Wilson [9], show that improving comfort was a priority for most of the occupants. Our approach will be to detect condominiums that function poorly and that have a strong potential for improvement. The idea is that it will be easier to propose thermal renovation in the same package as works to improve comfort.

\subsection{Economic Potential of the Occupants (and of the Building)}

Most of the studies $[10,11]$ and the feedback from professionals converge: one of the most important variables in a renovation project is the financial capacity of the owners.

However, it would be reductive to look only at the financial capacity of the occupants to judge the maturity of a condominium for renovation. There are several levers to be activated, which make it possible to finance part of work for householders with low revenues. It is also very important to measure all the parameters to evaluate the restoration potential correctly. 


\subsection{Technical Quality of the Building}

The studies in the OPEN report [12] highlight variations of 1 to 5 between the cost of a small renovation and a complete renovation. This statistic can vary according to the initial state of the building in energy terms (a larger energy profit will be more expensive on average). So the state of the building is a capital parameter because it changes the costs, and the profitability of the work.

\subsection{Sociological Profile of the Occupants}

Social criteria are useful to select the condominiums that have a strong potential for restoration and also to determine the accompaniment strategy to be adopted.

\subsection{Urban and Architectural Potential of the Building}

Information about the building and its district are helpful in the accompaniment strategy to succeed in convincing the occupants.

\section{Towards the Definition of Maturity for Renovation}

In the preceding part, we highlighted a certain number of criteria that determine the potential success of the thermal restoration operation. By grouping these criteria in the same decision-makingassistance tool, it will be possible to evaluate a condominium (or to compare it with other similar condominiums that have been renovated). We could then measure what we could call the "maturity rating" of a condominium, or its renovation potential.

In the preceding parts, we have highlighted the fact that private companies, as well as public bodies, are not sufficiently interested in condominiums. We can hope that private sector investment and public allocations will be more focused on operations on condominiums with a good "maturity rating", and then be able to finance this time of accompaniment.

The aim of this evaluation is not to limit it to a rough analysis of a grade, or to be interested only in the condominiums that have a better grade than the fixed limit. The objective will rather be to use the data in order to deduce the best accompaniment strategies, according to the grades in main categories, or even of the one obtained for a precise criterion.

\section{Conclusions}

Through the identification and categorization of all the criteria mentioned, we have proposed a means of identifying the "maturity" of a condominium to undertake renovation works.

However, our research does not take the relative importance of the criteria identified into account. The future model suggested does not highlight these differences of weight of each criterion and little work has been done on this subject.

From our point of view, studying cases can guide us to highlight the criteria that are the most important. Only a statistical study on a large number of condominiums that made the choice to subscribe to a renovation could enable the actual weight of each criterion to be determined. However, gaining access to this kind of database is a long and tedious task. The work of P. Caputo [13] shows how hard it can be to access building databases.

It will also be necessary to think about how possible it is for a user of the tool to find the data to fulfill these criteria. Unless the occupants can be met one by one (which takes time and money), it will be potentially complicated to obtain certain data (in particular certain social data, but also some given technical ones). Today, the French government is working on the creation of a complete database for all condominiums (via the condominium register: https://www.registrecoproprietes.gouv.fr). This database, if it becomes accessible, could simplify some of the work of the user of the tool, and help him to obtain reliable results. 
Lastly, the creators will not be able to come to each condominium to update the diagnostic software to its specific field study. Certain conflicts between individuals, or antagonisms can block restoration and such situations will never be detectable by computer tools, however powerful they may be.

\section{References and Note}

1. ADEME. Mener une Rénovation Énergétique en Copropriété; ADEME: Montrouge, France, 2014; 28p, ISBN 9782-35838-240-3.

2. ADEME. Réussir une Rénovation Performante; ADEME: Montrouge, France, 2014; 40p, ISBN 978-2-35838-481-0.

3. Projet ATHEBA. ATHEBA: Amélioration Thermique du Bâti Ancien; Fiches Techniques 2010; Produced by MPF and CETE Est, Partners: FFB, CAPEB, MEDDTL, MCCFP; Association Nationale de Sauvegarde du Patrimoine Rural Bati et Paysager: Paris, France, 2010.

4. ADEME. Travaux en Copropriété Comment sont Prises les Décisions?; ADEME: Montrouge, France, 2014; 10p.

5. Brisepierre, G. Comment se décide une rénovation thermique en copropriété? Un nouveau mode d'organisation de l'habitat comme condition de l'innovation énergétique. Flux 2014, 2, 31-39.

6. Brisepierre, G. Les Conditions Sociales et Organisationnelles du Changement des Pratiques de Consommation D'énergie dans L'habitat Collectif. Ph.D. Thesis, Université Paris Descartes, Paris, France, 2014.

7. PUCA/ANAH. Les Leviers pour Déclencher les Travaux; Amélioration Énergétique en Copropriété; Cahier 1, 2, 3, 4 et 5; Agence Nationale de L’habitat: Paris, France, 2012.

8. Wilson, C.; Crane, L.; Chryssochoidis, G. Why do homeowners renovate energy efficiently? Contrasting perspectives and implications for policy. Energy Res. Soc. Sci. 2015, 7, 12-22.

9. French law $n^{\circ} 2009-323$ of 25 March 2009 on mobilization for housing and the fight against exclusion ("mobilisation pour le logement et la lutte contre l'exclusion"), 2009. 2009-323.

10. OPEN: Observatoire Permanent de L'amélioration Énergétique du Logement. Campagne 2015. Available online: http://www.ademe.fr/open-observatoire-permanent-lamelioration-energetique-logement-campagne2015 (accessed on 17 April 2018).

11. CGDD. Les Perceptions Sociales Etpratiques Environnementalesdes Français de 1995 à 2011. Available online: http://www.statistiques.developpement-durable.gouv.fr/fileadmin/documents/Produits_editoriaux/ Publications/La_revue_du_CGDD/2011/Revue\%20CGDD_octobre\%202011.pdf (accessed on 25 April 2018).

12. RénovÉnergie: La Rénovation Énergétique des Logements du Secteur Privé. Available online: http:// www.ademe.fr/renovenergie-renovation-energetique-logements-secteur-prive (accessed on 17 April 2018).

13. Caputo, P.; Pasetti, G. Boosting the energy renovation rate of the private building stock in Italy: Policies and innovative GIS-based tools. Sustain. Cities Soc. 2017, 34, 394-404. 